\title{
VALIDATION OF THE BRAZILIAN-PORTUGUESE VERSION OF THE GESTURE BEHAVIOR TEST FOR PATIENTS WITH NON-SPECIFIC CHRONIC LOW BACK PAIN
}

\author{
Ricardo Furtado, Anamaria Jones, Rita NV Furtado, Fábio Jennings, Jamil \\ Natour
}

doi: 10.1590/S1807-59322009000200004

\begin{abstract}
Furtado R, Jones A, Furtado RNV, Jennings F, Natour J. Validation of the brazilian-portuguese version of the gesture behavior test for patients with non-specific chronic low back pain. Clinics. 2009;64:83-90.
\end{abstract}

OBJECTIVE: To develop a Brazilian version of the gesture behavior test (GBT) for patients with chronic low back pain. METHODS: Translation of GBT into Portuguese was performed by a rheumatologist fluent in the language of origin (French) and skilled in the validation of questionnaires. This translated version was back-translated into French by a native-speaking teacher of the language. The two translators then created a final consensual version in Portuguese. Cultural adaptation was carried out by two rheumatologists, one educated patient and the native-speaking French teacher. Thirty patients with chronic low back pain and fifteen healthcare professionals involved in the education of patients with low back pain through back schools (gold-standard) were evaluated. Reproducibility was initially tested by two observers (inter-observer); the procedures were also videotaped for later evaluation by one of the observers (intra-observer). For construct validation, we compared patients' scores against the scores of the healthcare professionals.

RESULTS: Modifications were made to the GBT for cultural reasons. The Spearman's correlation coefficient and the intra-class coefficient, which was employed to measure reproducibility, ranged between 0.87 and 0.99 and 0.94 to 0.99 , respectively $(p<0.01)$. With regard to validation, the Mann-Whitney test revealed a significant difference $(p<0.01)$ between the averages for healthcare professionals (26.60; SD 2.79) and patients (16.30; SD 6.39). There was a positive correlation between the GBT score and the score on the Roland Morris Disability Questionnaire $(\mathrm{r}=0.47)$.

CONCLUSIONS: The Brazilian version of the GBT proved to be a reproducible and valid instrument. In addition, according to the questionnaire results, more disabled patients exhibited more protective gesture behavior related to low-back.

KEYWORDS: Low back pain; Behavior; Patient education; Back school; Validation studies.

\section{INTRODUCTION}

Patient education refers a set of activities designed to improve and/or adapt patient behavior in relation to illness and therefore improve health with long-lasting results. ${ }^{1}$ Educational groups addressing low back pain that seek information on pain and, above all, behavioral changes have recently emerged. ${ }^{2}$ Available information indicates that poor gesture behavior is a risk factor for non-specific chronic low back pain.

Division of Rheumatoly, Federal University of São Paulo (UNIFESP), São Paulo/SP, Brazil

Email: jnatour@unifesp.br

Tel.: 5511 5576-4239

Received for publication on September 2, 2008

Accepted for publication on October 17, 2008
Despite evidence of the progressively harmful effects of biomechanical factors on the lumbar spine, few authors have proposed gesture evaluation in patients with low back pain. A French-language gesture behavior test (GBT) was recently developed for patients with chronic low back pain. The GBT is a valid, reproducible, responsive instrument composed of five tasks: 1) getting out of bed after sleeping; 2) sweeping under the bed; 3 ) lifting and carrying a trash can; 4) simulating tying laces of a shoe without assistance; and 5) arranging objects with different weights on shelves at various heights. A gesture evaluation card is used with a minimum score of 0 and a maximum score of 32 points, with higher scores denoting better postural behavior. The scores vary from task to task, ranging from 0 to 6 points for the first task, 0 to 7 points for the second, 0 to 8 points 
for the third, 0 to 5 points for the fourth and 0 to 6 points for the fifth. ${ }^{3}$

The aim of the present study was to translate and culturally adapt the GBT for a Brazilian audience, as well as to evaluate its reproducibility and construct validity for use with the Brazilian population.

\section{MATERIAL AND METHODS}

This study was conducted in two stages. First, translation and cultural adaptation of the GBT was performed for use with the Brazilian population. In the second stage, reproducibility and construct validity were measured in a population of patients between 18 and 65 years of age with non-specific low back pain. ${ }^{4}$ The patients were selected from the Rheumatology outpatient clinic of the Universidade Federal de São Paulo (UNIFESP). In addition, healthcare professionals closely involved in the education of patients with low back pain through back schools from the Rheumatology Rehabilitation Division were also included in the study.

Clinical, demographic and socioeconomic data were collected prior to the test. The Brazilian version of the Roland Morris Disability Questionnaire, ${ }^{5}$ a 0 to $10 \mathrm{~cm}$ Visual Analogue Scale (VAS) ${ }^{6}$ for low-back pain (where $0 \mathrm{~cm}$ means "no pain" and $10 \mathrm{~cm}$ means "unbearable pain") and a modified Schober test ${ }^{7}$ were also administered. In accordance with the Helsinki declaration, all participants signed a term of consent and the study was approved by the Ethics Committee of the Universidade Federal de Sao Paulo.

\section{Translation and cultural adaptation}

This phase followed the systematization proposed by Falcão et al. ${ }^{8}$ Translation into Portuguese (V1) was performed by a rheumatologist who was fluent in both French and Portuguese and was knowledgeable regarding the cultural adaptation of questionnaires and chronic low back pain. The Portuguese version (V1) was then back-translated into French by a native-speaking teacher of the language. Finally, the French version was revised by the two translators in order to obtain a consensual translation (V2). Necessary alterations were then made to the Portuguese version (V1). Cultural adaptation was carried out by a group of two rheumatologists, one educated patient (completed high school) and the aforementioned French teacher. This group carried out a detailed analysis of the test, substituting items that had potential comprehension problems with cultural equivalents, thereby creating the final translated version of the GBT adapted to the Portuguese language (V3).

\section{Evaluation of the GBT measurement properties}

To test inter-observer reproducibility, the test was applied to 15 healthcare professionals and 30 patients with non-specific chronic low back pain; each individual was simultaneously evaluated by two observers (Evaluator 1 and Evaluator 2), and the tasks performed by the two groups were videotaped. After one week, Evaluator 1 performed a second evaluation using the videotaped sessions to test intra-observer reproducibility. The construct validity of the GBT was tested by comparing the live scores provided by Evaluator 1 in the five pre-established tasks (getting out of bed after sleeping, sweeping under the bed, lifting and carrying a trash can, simulating tying the laces of a shoe without assistance and arranging objects of different weights at various heights) for Group 1 (healthcare professionals) and Group 2 (patients with low back pain).

\section{Statistical analysis}

Descriptive statistical analysis (average and standard deviation) was used for the clinical, demographic and socioeconomic variables. Inter-observer and intra-observer reproducibility was tested using Spearman's correlation coefficient (SCC) and the intra-class correlation coefficient (ICC). ${ }^{9}$ A non-parametric Mann-Whitney test was used to assess the construct validity of the GBT. ${ }^{10}$ The correlations between the GBT score and pain (VAS), ${ }^{11}$ disability (Roland Morris questionnaire), ${ }^{11}$ lumbar mobility (modified Schober test), ${ }^{11}$ income and schooling were calculated using Pearson's correlation coefficient (PCC). ${ }^{12}$ The relationship between GBT score and the categorical variables tobacco smoking and sedentary lifestyle were calculated using a t-test. ${ }^{13}$

\section{RESULTS}

After the translators reached a consensus, the Portuguese version of the GBT was culturally adapted through alteration of the statements in the five tasks while maintaining the original meaning. The final version of the GBT is attached (Appendix 1).

\section{Evaluation of the GBT measurement properties}

Thirty patients with non-specific chronic low back pain and fifteen healthcare professionals (five physicians, five physiotherapists and five occupational therapists) participated in the assessment of reproducibility and construct validity. The patient group had an average age of 50.3 years and was predominantly female $(66.6 \%)$. On average, the group had completed 5.9 years of schooling. The average monthly 
Table 1 - Clinical, demographic and socioeconomic characteristics of patients with low back pain

\begin{tabular}{ll}
\hline Average age in years (SD) & $50.3(9.5)$ \\
Gender - female: male & $2: 1$ \\
Average income, in Euros (SD) & $325.95(333.35)$ \\
Average schooling, in years of study (SD) & $5.9(3.7)$ \\
Average duration of illness, in years (SD) & $10.3(8.38)$ \\
Average time elapsed since diagnosis, in years (SD) & $6.76(6.91)$ \\
Average VAS score (SD) & $5.3(2.4)$ \\
Average RM score (SD) & $12.6(5.6)$ \\
Average Schober score (SD) & $4.4(1.2)$ \\
Sedentary & $14(46.6 \%)$ \\
Tobacco smoker & $6(20 \%)$ \\
\hline
\end{tabular}

$\mathrm{SD}=$ Standard Deviation

income of the patients was EUR \$325.95. The average duration of the illness was 10.3 years, and the average time that had elapsed since diagnosis was 6.76 years.

Regarding pain, the patients scored an average of 5.3 $\mathrm{cm}$ on the 0 to $10 \mathrm{~cm}$ Visual Analogue Scale (VAS) for pain. The average Roland Morris disability (RM) score was
12.6. Average lumbar mobility, as measured by a modified Schober test, was $4.4 \mathrm{~cm}$. Fourteen patients (46.6\%) led sedentary lifestyles, and six patients $(20 \%)$ were tobacco smokers. These results are displayed in Table 1.

Spearman's correlation coefficient and the intraclass correlation coefficient values for the inter-observer evaluation ranged between 0.87 and 0.97 and 0.94 and 0.98 , respectively, indicating statistical significance $(p<0.01)$ and high reproducibility. Table 2 displays these results, along with the averages (standard deviations) of the two observers for the five tasks and the overall GBT scores.

Table 3 displays the intra-observer reproducibility results as well as the averages (standard deviations) for the five tasks and the overall GBT scores based on the two observations made by a single observer (Evaluator 1) at different times (initially and seven days later). Table 3 also displays the values obtained from Spearman's Correlation Coefficient (0.94 to 0.99$)$ and the intra-class correlation coefficient $(0.97$ to 0.99$)$, which were statistically significant $(p<0.01)$ and demonstrated high reproducibility.

Construct validity was assessed by comparing the average scores on the five tasks and the overall scores of the thirty patients with chronic low back pain to the scores of

Table 2 - Inter-observer reproducibility according to Spearman's correlation coefficient (SCC) and intra-class correlation coefficient (ICC)

\begin{tabular}{|c|c|c|c|c|c|}
\hline \multirow[t]{2}{*}{ TASKS } & \multicolumn{2}{|c|}{ AVERAGE (SD) } & \multicolumn{2}{|c|}{ COEFFICIENTS } & \multirow[t]{2}{*}{ CI 95\% (ICC) } \\
\hline & Obs 1 & Obs 2 & ICC & SCC & \\
\hline Task 1 & $5.4(0.73)$ & $5.53(0.64)$ & $0.97 *$ & $0.95^{*}$ & $0.95-0.98$ \\
\hline Task 2 & $5.07(1.03)$ & $5.33(1.29)$ & $0.98 *$ & $0.95^{*}$ & $0.96-0.98$ \\
\hline Task 3 & $6.47(1.06)$ & $6.87(0.83)$ & $0.94 *$ & $0.88^{*}$ & $0.88-0.96$ \\
\hline Task 4 & $4.60(0.63)$ & $4.53(0.83)$ & $0.97 *$ & $0.87^{*}$ & $0.95-0.98$ \\
\hline Task 5 & $5.07(0.96)$ & $5.07(0.96)$ & $0.97 *$ & $0.95^{*}$ & $0.95-0.98$ \\
\hline Total & $26.6(2.8)$ & $27.33(2.77)$ & $0.98^{*}$ & $0.97 *$ & $0.97-0.99$ \\
\hline
\end{tabular}

SD- Standard Deviation; ICC - Intra-Class Correlation Coefficient; SCC - Spearman's Correlation Coefficient; Obs 1 - Observer 1; Obs 2 - Observer 2; $* p<0.01 ;$ CI $95 \%$ - 95\% Confidence Interval.

Table 3 - Intra-observer reproducibility according to Spearman's correlation coefficient (SCC) and intra-class correlation coefficient (ICC)

\begin{tabular}{lcclcc}
\hline TASKS & \multicolumn{2}{c}{ AVERAGE $(\mathrm{SD})$} & \multicolumn{2}{c}{ COEFFICIENTS } & \multicolumn{2}{c}{ CI 95\% (ICC) } \\
\cline { 2 - 5 } & Obs 1 & Obs $\delta 1$ & ICC & \multicolumn{2}{c}{ SCC } \\
\hline Task 1 & $5.53(0.64)$ & $5.53(0.64)$ & $0.99^{*}$ & $0.99^{*}$ & $0.99-0.99$ \\
Task 2 & $5.33(1.29)$ & $5.33(1.54)$ & $0.98^{*}$ & $0.97^{*}$ & $0.97-0.99$ \\
Task 3 & $6.87(0.83)$ & $6.93(0.79)$ & $0.97^{*}$ & $0.94^{*}$ & $0.95-0.98$ \\
Task 4 & $4.53(0.83)$ & $4.67(0.72)$ & $0.99^{*}$ & $0.96^{*}$ & $0.98-0.99$ \\
Task 5 & $5.07(0.96)$ & $5.00(0.92)$ & $0.98^{*}$ & $0.97^{*}$ & $0.97-0.99$ \\
\hline Total & $27.33(2.77)$ & $27.47(2.7)$ & $0.99^{*}$ & $0.99^{*}$ & $0.99-0.99$ \\
\hline
\end{tabular}

SD- Standard Deviation; ICC - Intra-Class Correlation Coefficient; SCC - Spearman's Correlation Coefficient; Obs 1 - Observer 1 (initial evaluation); Obs $\delta 1$ - Observer 1 (evaluation after seven days); * $p<0.01$; CI 95\% - 95\% Confidence Interval. 
the fifteen healthcare professionals with experience in back schools. The average overall score was 16.30 (ranging from 4 to 29 points) for patients with low back pain and 26.60 (ranging from 21 to 31 points) for healthcare professionals. The healthcare professionals were statistically superior to the patients in the performance of all tasks $(p<0.001)$ (Table 4).

Table 4 - Construct validity of the GBT

\begin{tabular}{|c|c|c|c|}
\hline \multirow[t]{2}{*}{ TASKS } & \multicolumn{2}{|c|}{ AVERAGE (SD) } & \multirow{2}{*}{$\begin{array}{c}\mathrm{P} \\
\text { (Mann-Whitney test) }\end{array}$} \\
\hline & Patients & Professionals & \\
\hline 1 & $2.93(1.76)$ & $5.40(0.73)$ & $<0.001$ \\
\hline 2 & $3.40(2.14)$ & 5.07 (1.03) & 0.014 \\
\hline 3 & 4.27 (2.03) & 6.47 (1.06) & 0.001 \\
\hline 4 & $2.93(2.06)$ & $4.60(0.63)$ & 0.013 \\
\hline 5 & $2.77(1.30)$ & $5.07(0.96)$ & $<0.001$ \\
\hline TOTAL & $16.30(6.39)$ & $26.60(2.79)$ & $<0.001$ \\
\hline
\end{tabular}

SD- Standard Deviation; Mann-Whitney test

Pearson's correlation coefficient was used to determine the correlations between GBT scores and the clinical, demographic and socioeconomic variables. The GBT score had a positive correlation with the Roland Morris Questionnaire score $(\mathrm{r}=0.47 ; p<0.01)$ (Table 5). The t-test revealed no statistically significant relationship between GBT and tobacco smoking or sedentary lifestyle.

Table 5 - Correlations between GBT score and clinical and demographic variables

\begin{tabular}{lcc}
\hline VARIABLES & PCC & P \\
\hline Age & -0.293 & 0.116 \\
Schooling & 0.261 & 0.163 \\
Duration of symptoms & 0.014 & 0.942 \\
Time since diagnosis & 0.016 & 0.935 \\
Income & 0.174 & 0.359 \\
VAS & 0.058 & 0.761 \\
Roland Morris Score & 0.470 & $0.009^{*}$ \\
Modified Schober Score & -0.283 & 0.129 \\
\hline
\end{tabular}

PCC - Pearson's Correlation Coefficient; $* p<0.01$

\section{DISCUSSION}

Low back pain is an obnoxious clinical entity which affects individuals in different walks of life. ${ }^{14}$ The aim of the present study was to translate, adapt and validate the gesture behavior test (GBT) for use in Portuguese populations using a standardized process reported in the literature. The GBT was chosen because it is the only valid, reproducible and responsive instrument for the evaluation of postural behavior in patients with low back pain cited in the literature. It demonstrated adequate cultural equivalence for our population. We opted to use the simplified cross-cultural adaptation process proposed by Falcão et al. ${ }^{8}$ This method has a lower execution cost as well as a shorter execution time than other methods suggested previously in the literature. Furthermore, it has been successfully for Portuguese language validation of other measurement instruments. ${ }^{15-17}$

In the evaluation phase of intra-observer and interobserver reproducibility, Spearman's correlation coefficients and the intra-class correlation coefficients revealed strong correlations between all five tasks and the overall GBT score, ranging from 0.87 to 0.99 . For this phase, we employed two healthcare professionals involved in educational groups of patients with low back pain through back schools. We also utilized a videotape recording for the assessment of intraobserver reproducibility. We opted to do so for multiple reasons: it would be difficult to have our patients return for a follow-up visit, we considered it a reliable measurement, and it was used in the original GBT validation. ${ }^{3}$ The aim of the construct validation process was to determine whether the test had the capacity to distinguish between two populations with different levels of knowledge regarding lumbar spine protection. We used healthcare professionals who were closely involved in the education of patients with low back pain through back schools to ensure that one group demonstrated a high level of knowledge.

The average age of our patients was 50.3 years (SD $=9.5$ ), which is higher than the sample age reported by Vanderthormmen et al. ${ }^{3}$ of 45.7 years $(\mathrm{DP}=10.8)$. Henrotin et al. ${ }^{18}$ state that the incidence of chronic low back pain increases with age; however, no correlation was observed in our study between age and GBT score.

Although the literature does not suggest a greater incidence of low back pain among women, ${ }^{4,19,20}$ our sample was predominantly female $(66.6 \%)$. We suspect that women are more likely to pursue and follow treatment, which may have increased the participation of females. Regarding pain, our patients achieved an average score of $5.3(\mathrm{SD}=2.4)$ on the Visual Analogue Scale $(0-10 \mathrm{~cm})$. This score is higher than that observed by Vanderthormmen et al, ${ }^{3}$ who found an average score of $34.1(\mathrm{SD}=25.9)$ using a scale from 0 to $100 \mathrm{~cm}$. We observed no correlation between pain and the GBT score.

There are numerous published reports of correlations between chronic low back pain and both tobacco smoking and a sedentary lifestyle; ${ }^{21}$ however, we observed no such correlations in the present study. This finding may be explained by the relatively small number of patients in our 
study, which may not have been sufficient to indicate a statistically significant correlation for these variables.

The patients evaluated in the present study achieved an average score of less than 50 percent of the maximum in Tasks 1 (getting out of bed), 2 (sweeping under the bed) and 5 (arranging objects on shelves). These results are similar to those observed by Vanderthormmen et al., ${ }^{3}$ who found that patients scored 43.9 percent, 35.1 percent and 40.3 percent of the maximum on Tasks 1, 2 and 3 (lifting and carrying a heavy trash can), respectively. This finding suggests that the failure of patients with chronic low back pain to protect the lumbar spine in the performance of daily tasks was similar in the two studies, despite the evaluation of different populations.

Considering the low level of formal education (less than 6 years of schooling) of the patients, we initially believed that the higher scores (greater than 50 percent of the maximum) obtained in Tasks 3 (lifting and carrying a trash can) and 4 (tying laces of a shoe) could be explained the patients' years of experience with the illness, which may have taught them to protect their backs. However, the GBT score exhibited no statistically significant correlation with either length of illness or time elapsed since the diagnosis, which does not support the hypothesis that the duration of the condition has a teaching effect that leads patients to perform these tasks in a more correct manner.

There was a positive, albeit weak, correlation between the GBT score and disability, as measured by the RM questionnaire $(\mathrm{r}=0.47 ; p<0.01)$. We believe that the disability caused by chronic low back pain leads patients to acquire skills that permit them to protect and not overload their vertebral columns. As the GBT assesses five daily activities, we suspect that the more incapacitated patients transferred this behavior to the task evaluated in the test. As these patients received no prior postural orientation, this transfer of behavior probably occurred in an unplanned fashion.

The evidence provided in the literature demonstrates the effectiveness of patient education in the treatment of chronic low back pain. Oleske et al. ${ }^{22}$ report that physically demanding work associated with poor ergonomic exposure is one of the risk factors for recurrence of low back pain. Thus, GBT could be used to assess patients that report performing significant housework and/or labor. We suggest that patients should be educated about lumbar spine protection so that they can apply this knowledge to their own activities.

We believe that the translation and validation of GBT is important as the Portuguese version may serve as both an assessment instrument for back schools and an informative tool that may be used by patients with low back pain and medical personnel to better understand the effects of posture. With proper education, modifications can be made to posture in an effort to control and/or avoid further episodes of low back pain. As our patient population had a low level of formal education (less than 6 years of schooling, the fact that the GBT is not a self-administered test, which would require and be affected by literacy, was beneficial. Through simple verbal commands, we specifically assessed patient behavior rather than asking the patients to answer written questions.

The present study demonstrates the need for a behavioral approach to non-specific chronic low back pain treatment. It also provides an instrument that can be used to evaluate gesture behavioral patterns of patients with chronic low back pain, thereby making it possible to assess and improve educational programs at back schools.

\section{CONCLUSIONS}

The present study developed a Brazilian version of the GBT. The GBT proved to be a reproducible and valid instrument for use on a Brazilian population of patients with non-specific chronic low back pain. Moreover, more disabled patients had better gesture behavior according to this instrument.

\section{ACKNOWLEDGEMENT}

We are grateful to the creator of the test dévaluation $d u$ comportement gestuel rachidien, Marc Vanderthommen, for permitting its use.

\section{REFERENCES}

1. Hill J. A practical guide to patient education and information giving. Baillieres Clin Rheumatol. 1997;11:109-27.

2. Cohen JE, Goel V, Frank JW, Bombardier C, Peloso, Guillemin F. Group education interventions for people with low back pain. Spine. 1994;19:1214-22.
3. Vanderthommen M, Boulanger AS, Defaweux M, Tomasella M, Crielaard JM. Validation of an evaluation test of activities of daily living behaviour for patients with chronic low back pain. Ann Reádaptation Méd Phys. 2001;44:281-90.

4. Frymoyer JW. Back pain and sciatica. N Eng J Med.1988; 318:291300 . 
5. Nusbaum L, Natour J, Ferraz MB, Goldenberg J. Translation, Adaptation and Validation of Roland Morris Questionare-Brazil Roland -Morris. Braz J Med Biol Res. 2001;34;203-10.

6. Tosteson AN. Preference - Based health Outcome Measures in Low back Pain. Spine. 2000;25:3161-66.

7. Leclaire R, Esdaile JM, Suissa S, Rossignol M, Proulux R, Dupuis M. Back School in a First Episode of Compensated Acute Low Back Pain: A Clinical Trial to Assess Efficacy and Prevent Relapse. Arch Phys Med Rehabil. 1996;77:673-9.

8. da Mota Falcão D, Ciconelli RM, Ferraz MB. Translation and Cultural Adaptation of Quality of Life Questionnaires : An Evaluation of Methodology. J Rhematol. 2003;30:379-85.

9. Nichols DP. Choosing an Intraclass Correlation Coefficient, SPSS Keywords, Number 67, 1998. UCLA: Academic Technology Services, Statistical Consulting Group. from http://www.ats.ucla.edu/stat/sas/ notes2/ (accessed November 24, 2007)

10. Conover WJ. Practical Nonparametric Statistcs. 2nd Edition, New York: John Wiley \& Sons, Inc.

11. Ribeiro LH, Jennings F, Jones A, Furtado R, Natour J. Effectiveness of a back school program in low back pain. Clin Exp Rheumatol. 2008;26:818 .

12. Neter J, Wasserman W, Kutner, MH. Applied Linear Statistical Models. Irwin Inc. 1990

13. Hulley SB. Delineando a pesquisa clínica: uma abordagem epidemiológica. Porto Alegre: Artmed; 2003.
14. Andrusaitis, SF, Oliveira RP, Barros Filho TE. Study of the prevalence and risk factors for low back pain in truck drivers in the state of São Paulo, Brazil. Clinics. 2006;61:503-10.

15. Ferraz LB, Almeida FA, Vasconcellos MR, Faccina AS, Ciconelli RM, Ferraz MB. The impact of lupus erythematosus cutaneous on the Quality of life: the Brazilian-Portuguese version of DLQI. Qual Life Res. 2006;15:565-70.

16. Pires CPAB, Ferraz MB, Abreu MHNG. Translation into Brazilian portuguese, cultural adaptation and validation of the oral health impact profile (ohip-49). Braz Oral Res. 2006;20:263-8.

17. Ciconelli RM, Soárez PC, Kowalski CCG, Ferraz MB. The Brazilian Portuguese version of the Work Productivity and Activity Impairment - General Health (WPAI-H) Questionnaire. Sao Paulo Med J. 2006; 124:325-32.

18. Henrotin Y, Vanderthommen M, Fauconnier C, Grisart J, Masquelier É, Peretz A, et al. Definition, criteres de qualite et evaluation d'un programme de type ecole du dos. Recommandations de la Societe belge des ecoles du dos (SBED). 2001;68:185-91.

19. Deyo RA, Weinstein JN. Low back pain. N Eng J Med. 2001; 344:36370

20. Harwood M I, Smith B J. Low Back Pain: A Primary Care Approach. Clin Fam Pract 2005;7:279-303.

21. Manek NJ, Macgregor AJ. Epidemiology of back disorders: prevalence, risk factors and prognosis. Curr Opin Rheumatol. 2005;17:134-40.

22. Oleske DM, Lavender SA, Andersson GBJ, Morrissey MJ, ZoldKilbourn P, Allen C, et al. Risk Factors for Recurrent Episodes of Work-Related Low Back Disorders in an Industrial Population. Spine. 2006;31:789-98

\section{APPENDIX}

\section{ITEM 1 - TESTE DE AVALIAÇÃO DO COMPORTAMENTO GESTUAL (VERSÃO EM PORTUGUÊS)}

\section{Guia para a utilização do teste de avaliação do compor- tamento gestual (TCG)}

A avaliação gestual é realizada com a ajuda de uma ficha de avaliação. Esta avaliação se compõe de cinco tarefas funcionais. Cada tarefa é caracterizada por uma instrução padronizada que permite a pontuação de vários critérios. A pontuação de cada critério resulta da opção motora do paciente.

\section{RECOMENDAÇÃO AOS AVALIADORES}

Ler atentamente o guia de utilização (instrunções e critérios de pontuação).

As instrunções devem ser dadas individualmente.

Respeito rigoroso das condições materiais.

Padronização das instrunções dada aos pacientes.

Otimização do ângulo de vista do avaliador (perfil).

\section{TAREFA $\mathbf{N}^{0} 1$}

\section{Instruções ao paciente:}

Deite de costas na cama (altura $=59 \mathrm{~cm}$, largura $=90 \mathrm{~cm}$, comprimento $=205 \mathrm{~cm}$ ).

Fique na posição de repouso habitual.

Deitado de costas, levante pelo outro lado.

\section{Critérios de pontuação}

1. Utilização de três tempos ( $1^{\circ}$ tempo: sentado, $2^{\circ}$ tempo: decúbito lateral; $3^{\circ}$ tempo: decúbito dorsal) ao deitar (sim - não).

2. Atitude principal em repouso (dorsal ou lateral adaptado - lateral não adaptado - decúbito ventral). O item 'lateral adaptado'corresponde a uma flexão dos dois membros inferiores (flexão de quadril superior a $45^{\circ}$ ). $\mathrm{O}$ item 'lateral não adaptado' corresponde a uma posição de pernas extendidas ou uma flexão de quadris inferior a $45^{\circ}$ ou uma flexão de um único membro inferior. 
3. Manutenção do paralelismo das cinturas escapular e pélvica nas mudanças de posição (sim - não).

4. Utilização dos três tempos (decúbito dorsal, decúbito lateral e sentado) ao levantar (sim - não).

5. Extensão dos joelhos e impulso simultâneo dos membros superiores ao passar do decúbito lateral para a posição sentada ( sim - não).

\section{TAREFA $\mathbf{N}^{0} 2$}

\section{Instrunções ao paciente:}

Escolha uma vassoura entre as duas $(100 \mathrm{~cm})$ das quais uma você pode regular a altura.

Varra debaixo da cama de maneira que a vassoura atinja o outro lado.

\section{Critérios de pontuação:}

1. Escolha da vassoura regulável e regulação correta da altura (altura do ombro) (sim - não).

2. Posição dos membros inferiores (muito fletidos - médiofletidos - extendidos). O item "muito fletido' corresponde a uma flexão dos joelhos superior a $90^{\circ}$.

3. Inclinação do dorso (vertical ou oblíquo com apoio-oblíquo sem apoio - horizontal sem apoio). O item 'oblíquo com apoio' corresponde a um apoio do peito sobre uma coxa.

4. Flexão do dorso (fisiológica - arredondada). A resposta 'fisiológica'sub-entende o controle da manutenção raquidiana com conservação das curvaturas fisiológicas e principalmente da lordose lombar. A resposta arredondada sub-entende um posicionamento não controlado em cifose ou hipercifose completa.

5. Estabilidade da posição "ótima" e não ótima". O item ótima, corresponde a utilização de pelo menos três pontos de apoio (posições: 'um joelho no chão', posição ajoelhada, posição genupeitoral ou posição agachada com apoio manual sobre o leito). $\mathrm{O}$ item não ótima, corresponde a uma posição bipede normal ou a uma posição unipodal ou bipodal sobre as pontas dos pés.

\section{TAREFA N $\mathbf{N}^{\circ} 3$}

\section{Instruções ao paciente:}

Pegue uma grande lixeira (altura $=49 \mathrm{~cm}$, diâmetro $=52 \mathrm{~cm}$, peso $6 \mathrm{Kg}$ ) com tampa e duas alças (altura das alças $=42 \mathrm{~cm}$ ), e coloque emcima do móvel (altura $=90 \mathrm{~cm}$ ). Em seguida, coloque a lixeira no chão no local indicado.

\section{Critérios de pontuação :}

1. Avaliação prévia da carga (sim- não). O item 'sim' corresponde a uma ação gestual ativa visando a avaliação do peso da lixeira (elevação prévia rápida).

2. Posição da carga em relação ao corpo na elevação e transporte ('próximo ao corpo' - 'afastado do corpo')

3. Manutenção do paralelismo das cinturas escapular e pélvica na elevação, transporte e abaixar da lixeira (sim - não).

4. Posição dos membros inferiores ('muito fletidos'- 'médio-fletidos'- extendidos) (ver tarefa $\mathrm{N}^{\circ} .2$ ).

5. Inclinação do dorso (vertical - oblíqua - horizontal).

6. Flexão do dorso (fisiológica - arredondada).

\section{TAREFA $\mathbf{N}^{\circ} 4$}

Instruções ao paciente:

Finja amarrar sapatos. Afim de padronizar as respostas, nenhuma ajuda (cadeira, tamburete) deve ser posta a disposição do paciente.

\section{Critérios de pontuação:}

1. Posição dos membros inferiores ('muito fletidos'- 'médio-fletidos'- extendidos) (ver tarefa $\mathrm{N}^{\circ} 2$ ).

2. Inclinação do dorso ('vertical ou oblíqua com apoio''oblíquo sem apoio'- horizontal sem apoio'). (ver tarefa $\mathrm{N}^{\mathrm{o}}$ 2).

3. Flexão do dorso ('fisiológica'- 'arredondada'). (ver tarefa $\mathrm{N}^{\circ}$ 2).

\section{TAREFA $\mathbf{N}^{\circ} 5$}

\section{Instruções ao paciente:}

Organize em uma estante de cinco pratileiras (nível $1=5 \mathrm{~cm}$, nível $2=50 \mathrm{~cm}$, nível $3=95 \mathrm{~cm}$, nível $4=140 \mathrm{~cm}$ e nível $5=185 \mathrm{~cm}$ do chão) três tipos de objetos situados em uma caixa de plástico $(50$ x 40 x $30 \mathrm{~cm})$ :

Duas garrafas de plástico cheias de água $(2 \times 1,5 \mathrm{Kg})$;

Três potes de conserva $(3 \times 0,5 \mathrm{Kg})$;

Três rolos de papel toalha $(3 \times 0,05 \mathrm{Kg})$

Cada prateleira da estante só pode conter uma categoria de objeto.

A caixa contendo os objetos deve ser colocada a $3 \mathrm{~m}$ da estante. Um banco (altura $=50 \mathrm{~cm}$ ), colocado perto da estante estará à disposição do paciente.

\section{Critérios de pontuação:}

1. Elevação a partir do solo (correta- média- incorreta): Primeira possibilidade: o indivíduo eleva a caixa contendo o conjunto de objetos.

Segunda possibilidade: o indivíduo eleva consecutivamente um ou vários objetos contidos na caixa para organizá-los na estante.

$\mathrm{O}$ avaliador seleciona o item 'correto'se as pernas estiverem muito fletidas, o dorso vertical ou levemente inclinado e 'fisiológico', 'incorreto' se as pernas estiverem estendidas, o dorso horizontal e arredondado e 'médio' em caso de soluções intermediárias (pernas médio-fletidas, 
dorso oblíquo). Se várias elevações forem realizadas, o mais inadequado será pontuado.

2. Transporte da carga (próximo ao corpo - afastado do corpo):

Primeira possibilidade: o indivíduo transporta a caixa.

Segunda possibilidade: o indivíduo transporta consecutivamente um ou vários objetos contidos na caixa. Se vários transportes forem realizados, o mais inadequado será pontuado.

3. Aproximação da caixa ('sim'- 'não'): o indivíduo utiliza a solução de aproximar a caixa da estante?

4. Sobrelevação da caixa ('sim'- 'não'): o indivíduo utiliza a solução de colocar a caixa sobre o banco?

5. Nível de organização ('adequado'- 'inadequado'). O item 'adequado' corresponde à utilização dos níveis 2,3 e 4 com organização obrigatória das duas garrafas de água no nível 2 ou 3.

Dois avaliadores participam da avaliação: o primeiro guia o paciente e lhe dá as instruções padronizadas. O segundo observa o paciente e completa imediatamente a ficha de observação.Cada critério será pontuado com valores de 0 , 1, ou 2 envolvendo a alternativa correspondente à gestual do paciente. Esta pontuação leva em consideração um escore funcional global de 32 pontos (6 pontos para a tarefa $\mathrm{n}^{\circ} 1$, 7 pontos para a tarefa $n^{\circ} 2$ e 8 pontos para a tarefa $n^{\circ} 3,5$ pontos para a tarefa $\mathrm{n}^{\circ} 4$ e 6 pontos para a tarefa $\mathrm{n}^{\circ} 5$ ). Por fim, a ficha de avaliação permite, no espaço correspondente, a anotação de observações para cada tarefa.

\section{ITEM 2 - FICHA DE AVALIAÇÃO DO COMPORTAMENTO GESTUAL (VERSÃO EM PORTUGUÊS)}

NOME DATA

\begin{tabular}{|c|c|c|c|c|c|c|c|c|c|c|c|}
\hline TAREFA $\mathrm{N}^{\circ} 1$ & & & & TAREFA N ${ }^{\circ} 2$ & & & & TAREFA N ${ }^{\circ} 3$ & & & \\
\hline DEITAR NA CAMA & 2Pts & $1 \mathrm{Pt}$ & $0 \mathrm{Pt}$ & VASSOURA & 2Pts & $1 \mathrm{Pt}$ & $0 \mathrm{Pt}$ & LIXEIRA & 2Pts & 1Ps & OPs \\
\hline $\begin{array}{l}\text { Utilização } 3 \text { tempos } \\
\text { (deitar) }\end{array}$ & & $\operatorname{sim}$ & não & Regulável (ombros) & & $\operatorname{sim}$ & não & Avaliação prévia & & $\operatorname{sim}$ & não \\
\hline $\begin{array}{l}\text { Atitude principal de } \\
\text { repouso }\end{array}$ & $\begin{array}{c}\text { dorsal ou } \\
\text { lateral } \\
\text { adaptado }\end{array}$ & $\begin{array}{l}\text { lateral } \tilde{n} \\
\text { adaptado }\end{array}$ & ventral & Posição MMII & $\begin{array}{l}\text { muito } \\
\text { fletidos }\end{array}$ & $\begin{array}{l}\text { médio } \\
\text { fletidos }\end{array}$ & extendidos & Posição da lixeira & & $\begin{array}{l}\text { próxima } \\
\text { ao corpo }\end{array}$ & $\begin{array}{l}\text { afastada } \\
\text { do corpo }\end{array}$ \\
\hline $\begin{array}{l}\text { Paralelismo das } \\
\text { cinturas }\end{array}$ & & $\operatorname{sim}$ & não & Inclinação do dorso & $\begin{array}{l}\text { vertical ou } \\
\text { oblíquo } \\
\text { c/ apoio }\end{array}$ & $\begin{array}{l}\text { oblíquo } \\
\text { s/ apoio }\end{array}$ & $\begin{array}{l}\text { horizontal } \\
\text { s/ apoio }\end{array}$ & $\begin{array}{l}\text { Paralelismo das } \\
\text { cinturas }\end{array}$ & & $\operatorname{sim}$ & não \\
\hline $\begin{array}{l}\text { Utilização } 3 \text { tempos } \\
\text { (levantar) }\end{array}$ & & sim & não & Flexão do dorso & & fisiológica & arredondada & posição MMII & muito & médio & extendidos \\
\hline \multirow{2}{*}{$\begin{array}{l}\text { Extensão MMII e } \\
\text { impulsão MMSS } \\
\text { simultâneos (sentar) }\end{array}$} & & \multirow[t]{2}{*}{$\operatorname{sim}$} & \multirow[t]{2}{*}{ não } & \multirow[t]{2}{*}{ Estabilidade } & & \multirow[t]{2}{*}{ ótima } & \multirow[t]{2}{*}{ ñ ótima } & Inclinação do dorso & vertical & oblíqua & horizontal \\
\hline & & & & & & & & flexão do dorso & & fisiológica & arredondada \\
\hline Total & & & & Total & & & & Total & & & \\
\hline Observações: & & & & Observações: & & & & Observações: & & & \\
\hline
\end{tabular}

\begin{tabular}{|c|c|c|c|c|c|c|c|}
\hline TAREFA N $\mathrm{N}^{\circ} 4$ & & & & TAREFA N ${ }^{\circ} 5$ & & & \\
\hline $\begin{array}{l}\text { AMARRAR O } \\
\text { SAPATO }\end{array}$ & 2Pts & $1 \mathrm{Pt}$ & $0 \mathrm{Pt}$ & $\begin{array}{l}\text { ORGANIZAÇÃO } \\
\text { (ESTANTE) }\end{array}$ & 2Pts & $1 \mathrm{Pt}$ & $\mathrm{OPt}$ \\
\hline Posição MMII & $\begin{array}{l}\text { muito } \\
\text { fletidos }\end{array}$ & $\begin{array}{l}\text { médio } \\
\text { fletidos }\end{array}$ & extendidos & $\begin{array}{l}\text { Elevação a partir } \\
\text { do solo }\end{array}$ & correta & média & incorreta \\
\hline Inclinação do dorso & $\begin{array}{l}\text { vertical ou } \\
\text { oblíquo } \\
\text { c/ apoio }\end{array}$ & $\begin{array}{l}\text { oblíquo } \\
\text { s/ apoio }\end{array}$ & $\begin{array}{c}\text { horizontal } \\
\text { s/ apoio }\end{array}$ & Transporte & & $\begin{array}{l}\text { próximo } \\
\text { ao corpo }\end{array}$ & $\begin{array}{l}\text { afastado } \\
\text { do corpo }\end{array}$ \\
\hline Flexão do dorso & & fisiológica & arredondada & Aproximação da caixa & & $\operatorname{sim}$ & não \\
\hline & & & & Sobrelevação da caixa & & $\operatorname{sim}$ & não \\
\hline & & & & Nível de organização & & adequado & inadequado \\
\hline Total & & & & Total & & & \\
\hline Observações: & & & & Observações: & & & \\
\hline
\end{tabular}

